\title{
RIGHT TO WATER AS A (FUNDAMENTAL) HUMAN RIGHT
}

Ivana Đuras

https://doi.org/10.32701/dp.21.1.3

1 Then the angel showed me the river of life, rising from the throne of God and of the Lamb and glowing crystal — clear.

2 Down the middle of the city street, on either bank of the river were the trees of life, which bares twelve crops of fruit in a year, one in each month, and the leaves of which are the cure for the nations. (Rev 22:1-2)

My late father's prophetic words over thirty years ago that the wars will be fought in the future because of water, at the time when bottled water was an unknown term to us, except for sparkling water in litre bottles, at the time when no one was talking about severe pollution of deep waters, when there was no mass fish die-off when water shortages could only occur due to low pressure in multi-storey buildings, today they sound uncomfortably real and are increasingly the topic of scientific and professional meetings, political associations, whereas the need for constitutional protection of citizens' rights on drinking water arises.

If we discuss water in a biological context, we can notice that the water makes up around $72 \%$ of the mass, mostly present in muscles and the least in adipose tissue. Water makes up three-quarters of muscle tissue, one quarter in fat and one-fifth of the bone content. Water in the joints is in the form of synovial fluid, which allows normal movement of the joints, and water permeates the entire digestive system, lungs, spinal cord and $85 \%$ of the brain, which is in the weightlessness state, in a liquid substance, cerebrospinal fluid. A human embryo in the amniotic fluid would not survive without water in the womb. Water regulates body temperature and is responsible for a variety of chemical reactions to the multitude of chemical compounds, minerals, energy, vitamins and hormones that are essential for maintaining life and for circulating these substances through the body. As there are no

* Ivana Đuras, Senior Advisor, Constitutional Court of the Republic of Croatia: The views and opinions expressed in this article are the personal views of the author and not represent the official views of the Constitutional Court of the Republic of Croatia, Email: Ivana_Duras@usud.hr 
supplies of water nor salt in the human and animal body, which are essential for maintaining life, the balance of water and salts comes from the function of the kidneys which continuously release or retain water and salt. At the same time, the sensation of thirst dictates the body to consume water. Therefore, in the biological context for human and all other similar living beings, water is, like clean air, inevitable precondition for both health and survival, the primary element from which life has evolved.

The question, therefore, arises whether the politicians are aware of the importance and value of drinking water, have they adequately protected, through positive legislation, healthy sources of drinking water in national countries, and provided sufficient care for clean environment and the prevention of nature and soil pollution to maintain deep water pools clean and safe for the use in daily life.

Therefore, the text below presents the legislative framework for the protection of water treasures in the Republic of Croatia, followed by indirect constitutional and conventional norms for the right to water, as well as concrete constitutional protection of water and some ethically doubtful decision making of public bodies when it comes to use of water.

\section{Water within the legislative framework of the Republic of Croatia}

The Ministry of Environment and Energy, the holder of the water policy, provided E- consultation on the whole package of acts regarding water management, from 9 January until 8 February 2019: Draft Proposal on a Water Services Act, Draft Proposal on a Water Act, Draft Proposal on a Water Management Finance Act. Draft Proposal on a The Water Services Act regulates the entire issues of public water supplies and general wastewater procedures, carry out institutional reform of water service providers, whose primary objective is to provide citizens with a fair price for water, and subsequently to investments in communal water constructions primarily means for wastewater treatment and sewage network, which the Republic of Croatia has adopted under the Treaty of Accession to the European Union.

The currently valid Water Act stipulates in Article $4^{1}$ that the water management consist of all the activities, measures and actions based on this Act and acts that regulate water management finance adopted by Hrvatske vode (Croatian Waters) of the Republic of Croatia and local (regional) authorities. Article 5 specifies that water is not a commercial product like other products, but it is a heritage that should be protected, and use wisely and 
rationally, the water should be managed according to the principles of water system unity and sustainable development, that meet the needs of the present generation and do not threaten the right and opportunities of future generations to come.

Water is also protected by Article 7 of the Water Act, which clearly states that water is a common good and has special protection of the Republic of Croatia and that surface- and ground-water cannot be the subject of property rights and other real rights.

In addition to the law mentioned above, which adequately protected the water treasure of the Republic of Croatia as national possession, there are several subordinate legislation, regulations, ordinances, decisions and state plans that prescribe in more detail the individual institutes of the law itself. It is essential to mention two other acts that directly address specific water issues, namely the Water Management Finance Act $^{2}$ and the Water Consumption Act. ${ }^{3}$ The first law affirms the sources of funding for water management, in particular, water fees, including the obligation to pay, enforcement, statute of limitations and other issues related to the realisation and use of these funds, while the other regulates health and safety of water for human consumption, competent authority for law enforcement and the mode of reporting to the European Commission on law enforcement, obligations of legal entities providing water for human consumption in the Republic of Croatia, methods of treatment and reporting in the event of deviation from the compliance to parameters for water human consumption, monitoring and other official controls on the health of water for human consumption and their financing, all to protect human health from the adverse effects of any pollution and ensure the health standards of water for human consumption in the Republic of Croatia.

\section{Do the Constitution and Convention protect the right to water?}

We can classify human rights into three categories of rights: civil and political rights, social and economic rights and the rights of the third generation. The first generation of human rights thus includes freedom of expression, dignity, right to life, right to a fair trial and the second generation comprises, for example, the right to a decent standard of living, the right to health, the right to education, the right to work, free elections and the like. The third generation of human rights is the collective right of a society or people, such 
as the right to sustainable development, peace or a healthy environment, which would certainly include the right to drinking water access for everyone. Namely, the rights of the third generation are related to the awareness of the sustainable development of life on Earth, which is why they mainly protect the natural environment and affirm the rights of other living beings on Earth, besides human. Most often, these are constitutionalised guarantees of a healthy life, clean air and environment, the rights of animals and plants to be protected from threats in order to conserve biodiversity. It is this last generation of human rights and the need for their more detailed approach in the context of Constitution indicates the constant change and development of human rights, whose protection is proof of the recognition of new issues that threaten the right to life, a fundamental human right protected by all modern democratic constitutions and all international acts. The Constitution of the Republic of Croatia protects the right to life by Article 21.

However, the Convention for the Protection of Human Rights and Fundamental Freedoms ${ }^{4}$ and its Protocols do not have in their text direct protection of water as a (fundamental) human right.

In spite of the above, the current constitutions in Europe, including the Constitution of the Republic of Croatia ${ }^{5}$, protect the right to drinking water indirectly through third-generation human rights. Our Constitution already stipulates in Article 2, Paragraph 4, Indent 2, that it is the Croatian Parliament that decides on the conservation and use of natural and cultural resources, which is a guarantee that without a parliamentary majority there will be no new regulation governing the right to water, there is no encroachment, alteration or diminution of the rights guaranteed by law, nor even the rights, as stated above, in Article 7 of the Water Act.

The next level of indirect protection of the right of water, our Constitution prescribes in Article 69, Paragraph 2 and 3, in which the state is obliged to provide conditions for healthy environment, and every individual is required, within one's powers and activities, to pay special attention to the protection of human health, nature and the environment. Similar, indirect and derivative protection of the right to water is found in the constitutions of the former Yugoslavia republics and other European member countries. For example, Finland prescribes environmental responsibility as follows:

4 Convention for the Protection of Human Rights and Fundamental Freedoms, Official Gazette - International treaties, No 18/97, 6/99 — Revised text, 8/99 — Corrigendum, 14/02 and $1 / 06$.

5 Constitution of the Republic of Croatia, Official Gazette, No 56/90, 135/97, 113/00, 28/01, $76 / 10$ and $5 / 14$. 


\section{"Section 20 - Responsibility for the environment}

Nature and its biodiversity, the environment and the national heritage are the responsibility of everyone.

The public authorities shall endeavour to guarantee for everyone the right to a healthy environment and for everyone the possibility to influence the decisions that concern their living environment." 6

Other foreign and international political bodies do not explicitly protect the right to water, but it is noticeable from provisions that generally prescribe environmental protection, biodiversity or human health. Thus, in 1999, the Committee of Ministers of the Council of Europe published a "Declaration and Programme on Education for Democratic Citizenship based on the rights and responsibilities of citizens" which insists on strengthening citizens' awareness on their rights and responsibilities so they "develop a capacity to exercise these rights and respect the rights of others." The Declaration and the Program mention the responsibility of the individual and the "shared responsibility "of citizens. Responsibilities that are stated are also the preservation of a healthy and highly valued natural environment as well as an environment built by human. Two years earlier, the UNESCO General Conference adopted 12 November 1997 the "Declaration on the Responsibilities of the Present Generations Towards Future Generations" stated that states, the United Nations system, other intergovernmental and non-governmental organisations, individuals, public and private bodies should assume their full responsibility in the protection of the rights and freedoms of future generations, especially concerning the protection of the environment, the human genome, biological and cultural diversity, peace and the common heritage of humanity. One year later, the UN General Assembly adopted the "Declaration on the Right and Responsibility of Individuals, Groups and Organs of Society to Promote and Protect Universally Recognised Human Rights and Fundamental Freedoms". It emphasises the political responsibility of the government of the Member States, but also the "responsible attitude" of the individual.

Furthermore, the General Conference adopted the Universal Declaration on Bioethics and Human Rights of UNESCO on 19 October 2005 and also indirectly through Article 17 protected the environment, biosphere and biodiversity, stating that due attention should be focused to the interrelations of human beings and other forms of life, importance of appropriate approach

$6 \quad$ Nature and its biodiversity, environment and national heritage (treasure, heritage) are the responsibility of each individual. Public authorities will endeavour to guarantee everyone the right to a healthy environment and the ability to influence decisions regarding their living environment. 
and use of biological and genetic resources, respect for traditional knowledge, and the role human beings undertake in protecting the environment, the biosphere and biological diversity.

From the presented normative frameworks, it is evident that there is no direct protection of water as a (fundamental) human right, neither in the conventions nor in the constitutional texts nor the declarations of international bodies.

\section{Some doubtful decision making by foreign public bodies}

The European Parliament's Committee on Environment in Brussels rejected a petition form the eco-activist group "Right2Water" signed by 1.6 million European citizens to declare drinking water a universal human right, aligning itself to a political elite that proclaims water a multi-practical or multiuseful, thus allowing commercialisation and, thereby, privatisation of drinking water sources.

In March 2013, the Members of German Parliament passed a law that right to drinking water is no longer on the list of fundamental human rights, in a way that 299 members considered that water is not a human right and voted in favour of corporate ownership of drinking water, 75 did not vote, 124 members abstained, and 122 members voted against the privatisation of water.

Today we are faced with the fact that in the Republic of Croatia, foreign companies are taking over large corporations such as Dukat, companies related to Agrokor (Ledo, Jamnica, PIK Belje, Vupik etc.) together with factory plants, they are taking over ownership by succession contracts, ${ }^{7}$ not only of buildings but also lands, enabling them to pump drinking water sources, that is now owned by them, without concession. Therefore, even though water is protected by law, the question arises whether in specific cases the protection of property under the Article 48 of the Constitution as a secondgeneration constitutional right will overpower the country's right to manage drinking water sources, as required by Article 7 of the Water Act, as the constitutional third-generation right and only indirectly protected?

7 Act on Conversion of Socially Owned Enterprises, Official Gazette 19/91 and the Privatisation Act, Official Gazette 21/96 while converting socially-owned enterprises into companies with joint stocks that were subsequently sold to individuals in the privatisation process, each social-owned enterprise in the statement of property was a necessary document in the conversion process, together with the plant, for example, some factories, being sold with the total of all property, including their respective properties as forests, fields, arable land or ponds. The underwriters changed ownership structure, so by further sale for these transformed and privatised companies there is a possibility that properties rich in clean water will come into the ownership of persons who will pump clean water sources without paying a concession to the Republic of Croatia. 
Poor examples of privatisation of natural water sources are witnessed in numerous European countries, starting with Germany and France, in which the water supply was privatised to increase the prices of the services and water itself while reducing the quality of services and water, and then after privatisation returned to the management of the country or the local level, that is, in the domain of public sector, such as in Paris.

The example of Berlin, where a part of the water industry was privatised in the late 1990s, led to the continuous rise in prices and profit margins for private companies that raised prices and water services by $30 \%$ while investing almost nothing in infrastructure. Evelyne Gebhardt, member of Social Democratic Party and member of European Parliament, considers the city of London to be an extreme case of failed privatisation of water supply, in which about $40 \%$ household water was seeping into the ground since the company that privatised the water supply did not invest in infrastructure, specifically water pipes, led to loss of large quantities of drinking water to pollution of wastewater, and to an increase in the cost of water and water-related services to make up for the damage that ultimately citizens had to pay.

For this reason, in 2004, for example, the Netherlands' Government passed a law prohibiting the privatisation of water supply, and the Italian Constitutional Court ruled out that any future attempt to privatise public service would be contrary to the Constitution. Notwithstanding the aforementioned, European Commission reports show that Eurozone members who are unable to settle their debts are subject to the privatisation of drinking water sources. Activist groups informed Commissioner of the European Commission Olli Rehn about this practice, demanding that "further pressure to impose water privatisation" on Greece, Portugal and other countries in a similar situation to be stopped, as such procedure by the European Commission is contrary to the Treaty on European Union. ${ }^{8}$ The provisions governing the management of drinking water sources are not within the exclusive or shared jurisdiction of the Union but, contrary, fall under the authority of each member state. Moreover, Article 6 of the Treaty on the Functioning of the European Union, describes that Union should have the least influence in the policies of its members, stipulating that the Union should take actions to support, coordinate or complement the activities of the member states; at European level, such action applies only to the following areas: protection and improvement of health, industry, culture, tourism, education, vocational education, youth and sport, civil security and administrative cooperation. 


\section{Who straightforwardly protected the right to water?}

The survey conducted for the purpose of this paper found that only the Republic of Slovenia directly protected the right of its citizens to drinking water, as required by the standards set out in United Nations Resolution 64/292 in 2010, which will be discussed later.

The Constitution of the Republic of Slovenia ${ }^{9}$ originally stipulates the right to drinking water in the following way:

Article 70a

(Right to Drinking Water)

Everyone has the right to drinking water.

Water resources shall be a public good managed by the state.

As a priority and in a sustainable manner, water resources shall be used to supply the population with drinking water and water for house-

hold use and in this respect shall not be a market commodity.

The supply of the population with drinking water and water for household use shall be ensured by the state directly through self-governing local communities and on a not-for-profit basis.

It is clear from Article 70a of the Constitution of the Republic of Slovenia that everyone has the right to drinking water, that water sources are a common good and are managed by the state and that their primary purpose is to supply the population and economies with drinking water, which therefore cannot be in that matter a subject of free market. The state, directly and free of charge through local self-government units, maintains the supply of the population with drinking water.

The question arises how come Slovenia has not been affected by EU policy to commercialise drinking water, especially given that this provision ${ }^{10}$ was incorporated into the Slovenian Constitution only at the end of 2016.

In the context of the who and when was the right to water as a (fundamental) human right protected, it is inevitable to mention United Nations General Assembly Resolution 64/292 on 28 July 2010, by which the UN General Assembly recognised the human right to water and sanitation, as well as acknowledged that clean water and sanitation are essential to the realisation of all other human rights. The resolution invites signatory states and international organisations to provide funding, supporting structures

Uradni list RS, št. 33/91-I, 42/97 - UZS68, 66/00 - UZ80, 24/03 - UZ3a, 47, 68, 69/04

- UZ14, 69/04 - UZ43, 69/04 - UZ50, 68/06 - UZ121,140,143, 47/13 - UZ148, 47/13

— UZ90,97,99 in 75/16 — UZ70a

10 Dopolnitev - datum razglasitve 25. 11. 2016; UL RS, št. 75/16 z dne 30. 11. 2016. Z Ustavnim zakonom o spremembah III. poglavja Ustave RS (UZ70a) je bil dodan novi 70.a člen 
(infrastructure) and water transfer technology to help countries, especially developing countries, provide safe, clean, affordable and accessible drinking water and sanitation for all.

In 2002, the Office of the United Nations High Commissioner for $\mathrm{Hu}-$ man Rights ${ }^{11}$ repeatedly articulated his views on the importance of drinking water. Thus, in the area of "Human Rights, Poverty Reduction and Sustainable Development: Health, Food and Water", it emphasised that the human right to drinking water is fundamental to life and health. Sufficient and safe (healthy) drinking water is a prerequisite for the realisation of all other human rights. The upcoming global crisis, which will reach water, food and a safe environment at the same time, is one of the most challenging for sustainable development. The High Commissioner further stressed that a Member States (referring to UN members) have a vital obligation to provide the population with at least a minimum basic level of drinking water rights, and that, especially in the times of restrictions and necessary limitations on water consumption, vulnerable and marginalised populations had to be supplied with water at, for them, reasonable price. The High Commissioner continues to elaborate that the need for drinking water belongs to everyone and he believes that the right to drinking water should be safe, affordable and accessible for personal and domestic daily use. Drinking water should be considered in correlation with human dignity and not perceive water as a quantitatively determined technological and economic good.

\section{Final reflections}

In the biblical texts, water is present from the very creation of a man as a God's creation, through the flood that suppressed all sins of the first people to the water of salvation and purification brought to us by Christ and the sacraments, to the water of encounter of New and final life. It is clear that water, as the biological maximum in the body of human and other living beings, represents the condition sine qua non of the very existence of the living world. That is why water is also a symbol of the New Life, which the New Testament text bring to us through the encounter of Jesus and the Samaritan women, when he told her, "If you knew the gift of God, and who it is that is saying to

11 Office of the United Nations High Commissioner for Human Rights is a United Nations agency, which advocates protection and human rights guaranteed by international law and set out in the 1948 Universal Declaration of Human Rights. The High Comissiariat established by the UN agency since 20 February 1993 on the eve of the World Conference on Human Rights. The Commissariat is chaired by the High Commissioner for Human Rights, who co-ordinates human rights activities across the UN system and oversees the Human Rights in Geneva, Switzerland. 
you, 'Give me a drink,' you would have asked him, and he would have given you living water." Water creates, maintains, cleans and farewell at last.

Insufficient awareness of contemporary policies about the importance and necessity of healthy water accessibility to everyone is needed like the air to all living beings in this world leads to the sole goal for these policies, and that is the profit behind commercialisation of springs, deep water pools and infrastructures of water supply and water supply networks worldwide. Although the paper points out that there are states, senior international officials and civic initiatives that have unambiguously and publicly spoken out about the importance of clean and drinking water for all, protecting the exclusive right of the country and its citizens to their water supplies, and on the other hand executive policies on legislative and contractual platform, as a rule, give priority to the privatisation and commercialisation of water.

That way, for example, the Act on Strategic Investment projects of the Republic of Croatia, established the criteria and procedure for applying strategic investment projects, the procedure for evaluating, selecting, preparing and implementing strategic projects, property management owned by the Republic of Croatia for the implementation of strategic projects, granting concessions regarding the implementation of strategic projects, and issuing administrative documents related to the implementation of strategic projects. Given that the law defines that the strategic investment project is any private investment project, public investment project or public-private investment project in the field of economy, mining, energy, tourism, transport, infrastructure, electronic communications, postal services, environmental protection, agriculture, forestry, water management, fishing, health, culture, audio-visual activities, science, defence, justice, technology and education, which includes the construction of buildings, on the ground of this Act proclaimed by the Government of the Republic of Croatia, has the legislator opened the way to the concession of land and forests to private economic entities, who with concession are also granted the right to pump the associated drinking water sources in the area covered by the concession?

The answer to this question may be given by the fact that for a while, a litre of milk is cheaper than a litre of bottled water.

Therefore, as concluding argument of this paper, an amendment to the Universal Declaration of Human Rights should be proposed, which would include Article 31, which by the suggestion of one citizen's initiative could be included with minimal modification as an inherent part of our Constitution, as follows:

"Everyone has the right to clean water and access to water, sufficient for the health and well-being of individuals and families, and no one should be deprived of such access nor the quality of water for the individual economic benefit." 